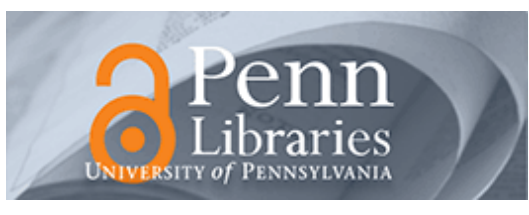

University of Pennsylvania
ScholarlyCommons

University of Pennsylvania Museum of Archaeology University of Pennsylvania Museum of Archaeology and Anthropology Papers and Anthropology

1989

\title{
What Mean These Seeds: A Comparative Approach to Archaeological Seed Analysis
}

Naomi F. Miller

University of Pennsylvania, nmiller0@upenn.edu

Follow this and additional works at: http://repository.upenn.edu/penn_museum_papers

Part of the Archaeological Anthropology Commons

\section{Recommended Citation}

Miller, N. F. (1989). What Mean These Seeds: A Comparative Approach to Archaeological Seed Analysis. Historical Archaeology, 23

(2), 50-59. Retrieved from http://repository.upenn.edu/penn_museum_papers/51

This paper is posted at ScholarlyCommons. http://repository.upenn.edu/penn_museum_papers/51

For more information, please contact repository@pobox.upenn.edu. 


\title{
What Mean These Seeds: A Comparative Approach to Archaeological Seed Analysis
}

\begin{abstract}
Since uncharred seeds recovered from archaeological deposits may be modern intrusions, researchers must evaluate each uncharred seed assemblage before assigning archaeological significance to it. When depositional circumstances are established, seed remains can yield primary data about diet, farming practices, and the spread of imported cultigens. Three uncharred seed assemblages are evaluated-one from Morven (Princeton, New Jersey) and two from the Calvert site (Annapolis, Maryland). The Morven seeds are modern. Seeds from a dry crawl space at the Calvert site probably date to the late 18th century, but rodent disturbance could have introduced more recent materials. Waterlogged seeds from a sealed 18th century well most securely reflect 18 th century debris.
\end{abstract}

\section{Disciplines}

Archaeological Anthropology 
NAOMI F. MILLER

\section{What Mean These Seeds:}

\section{A Comparative Approach to Archaeological Seed Analysis}

\section{ABSTRACT}

Since uncharred seeds recovered from archaeological deposits may be modern intrusions, researchers must evaluate each uncharred seed assemblage before assigning archaeological significance to it. When depositional circumstances are established, seed remains can yield primary data about diet, farming practices, and the spread of imported cultigens. Three uncharred seed assemblages are evaluatedone from Morven (Princeton, New Jersey) and two from the Calvert site (Annapolis, Maryland). The Morven seeds are modern. Seeds from a dry crawl space at the Calvert site probably date to the late 18 th century, but rodent disturbance could have introduced more recent materials. Waterlogged seeds from a sealed 18th century well most securely reflect 18 th century debris.

\section{Introduction}

Plant remains from archaeological sites have long been valued by prehistoric archaeologists concerned with such questions as the origins of agriculture, forager adaptations, and the agricultural economies of ancient complex societies. Whatever the time period or geographical area, however, plant remains provide important primary data about the natural environment, land use practices, trade in exotic plant materials, and diet. Of special interest to historical archaeologists are archaeobotanical studies which address such issues as the introduction and spread of new crops (Blake 1981) and ethnic and class differences in diet (cf., Reitz and Scarry 1985; Reinhard, Mrozowski, and Orloski 1986).

The interpretation of an archaeobotanical seed assemblage is rarely self-evident, however. The analyst must consider how plant materials arrived on the site and how they became preserved. That is, how did cultural practices and natural condi- tions "filter" the materials that are recovered? It is important to distinguish naturally occurring seeds from those deposited as a result of human activities. Ordinarily, archaeobotanists assume charred seeds are culturally significant for two reasons. First, since they have no food value, charred seeds are unlikely to be brought to a site by birds, rodents, or insects. Second, barring archaeological indications of unintended, natural burning, it is assumed that charring is a result of human activity, so in at least that minimal sense, charred seeds are cultural artifacts.

It is not valid to interpret uncharred seeds in the same way. Such seeds do not persist in the soil indefinitely. Archaeobotanists' experience has been that uncharred wood and fresh seeds are generally not preserved in open-air, moist soils, and that they are only poorly preserved in open-air, dry soils (Miksicek 1987). It is near the modern surface that frequent wetting and drying promote organic decay and that animal disturbance is most severe. If a historic site is not deeply stratified, uncharred materials will not last. For example, citing work done by R.E. Gasser and E.C. Adams in the southwestern United States, Miksicek (1987) relates that "only $0.3 \%$ of the seeds in deposits younger than 60 years were charred, whereas $8.6 \%$ of the seeds from rooms over 65 years old were carbonized. Microbial, rodent, and insect activity had destroyed some of the unburned plant material in the older sample."

Even though archaeobotanists usually consider uncharred seeds to be recent (Minnis 1981; Lopinot and Brussell 1982), extraordinary circumstances of preservation are known to occur, where physical, chemical or biological degradation has been slowed. Given a suitable environment, even the most fragile uncharred organic remains will last. Privy deposits are well-known sources of uncharred, mineralized seeds (Green 1979; Rock and Newsom 1987). Dry rockshelters in Arkansas have yielded late prehistoric desiccated pigweed and goosefoot seeds (Fritz 1984), and waterlogged material from Neolithic period Swiss lake dwellings have been known for over a century (Heer 1878). In order to evaluate the age of an uncharred seed assemblage, one must therefore consider the 
sturdiness of the seeds, the preservation environment of the archaeological deposit itself, possible old and new sources of seeds, and the cultural context of the deposit.

Uncharred seed remains from the grounds of two 18th century estates, Morven in Princeton, New Jersey, and the Calvert site in Annapolis, Maryland, show that before one can begin to reconstruct gardening practices, vegetation, or diet from seed remains, it is necessary to establish how and when the plant materials arrived on the site. One of the best ways to do this is by comparing assemblages from different depositional contexts, both within and between sites. Botanical material from Morven provides an opportunity to compare excavated plant remains with seed types produced by modern vegetation at the site, while the Calvert data allow one to compare seed samples structured by different circumstances of preservation and deposition.

\section{Morven}

In the 18th century, Morven was the home of Richard Stockton, one of the signers of the Declaration of Independence. The original estate was several thousand acres, but today, the remaining 4.5 acre property is surrounded by the lawns, parking lots, and streets of Princeton. The 1987 excavation uncovered 19th and 20th century deposits, though many 18th century artifacts were also found. Prior to excavation, most units were covered by brick paving or lawn. As part of the ethnobotanical research funded by the New Jersey State Museum and Department of State, a vegetation survey of the grounds was conducted, and 19 flotation samples were taken in order to retrieve small scale plant remains (Miller 1988).

The character of the archaeological deposits at Morven and of the seeds themselves suggests that the uncharred seeds recovered through flotation are recent intrusions. The vegetation survey revealed that the most likely sources of these seeds are the present day garden weeds.

The 1987 Morven flotation samples come primarily from open-air contexts-lawn and court- yard areas. Most of the 1987 excavation extended no deeper than one foot, where organic decay and faunal disturbance are most severe. Nonetheless, flotation samples were taken from near the present ground surface to see what seeds would be found in the upper soil levels. Although it seemed likely that the species list would resemble that of the modern surface vegetation, it was important to verify the potential sources of modern seeds in order to evaluate the archaeological significance of any uncharred excavated seeds.

One seed, an uncharred peach pit, was found during excavation between one and two feet below the present surface in 19th century fill above an 18 th century terrace. Since peach pits are sturdy, and there are no peach trees growing in the area today, this specimen probably dates to the 19th century.

The rest of the seeds were recovered through flotation (Table 1). They include seeds of trees and shrubs, as well as many weed seeds. The few tree seeds come from Norway spruce, magnolia, tulip poplar, and cherry. All of these types grow in the backyard today. Spruce seeds are delicate and are unlikely to persist in the soil for very long. The Norway spruces at Morven are less than 100 years old (Lockwood 1988), and these seeds are probably even more recent. Of the four tree types, only cherry produces sturdy seeds, and the pits found at Morven could come from these trees on the site or bird droppings.

As for the shrubs, both elderberry and bramble seeds are fairly common in the samples. Both seed types are moderately sturdy. There is a bramble bush on the property but not a single elderberry. However, as both bramble and elderberry are favored by birds, one can easily imagine these seeds dropping onto the grounds from elsewhere.

The vast majority of seeds, however, are tiny thin-walled weed seeds. Carpetweed and chickweed are the most numerous, and they occur in every sample. An inventory of the weeds in a patio adjacent to the mansion revealed carpetweed and chickweed growing in the cracks between the bricks. The flotation samples contain the seeds of several other plants that grow between the bricks of the patio (Table 1). They include goosefoot, 
TABLE 1

UNCHARRED SEEDS FROM MORVEN*

FRAGILE

WEED

TREE

SOMEWHAT

FRAGILE

WOODY
WEED

TREE, SHRUB

TREE buttercup, carpetweed, copperleaf, crownbeard, dandelion, goosefoot, goosegrass, other grass, nightshade, plantain, pokeweed, purslane/chickweed, sedge, smartweed, spurge, St. John's wort, wood sorrel, violet

conifer, spruce, tulip poplar, bramble, elderberry, Indian strawberry, locust, magnolia cherry

*See Appendix for Latin names of plants.

dandelion, copperleaf, goosegrass, crab grass, yellow wood sorrel, and common nightshade. Other types are shared by the flotation samples and the lawn and garden beds, especially Indian strawberry, yellow wood sorrel, and pokeweed. Although some of the uncharred seeds come from plants that have not been seen on the grounds of Morven (namely, elderberry), most of the common types grow adjacent to or over the excavation units.

In summary, both the poor conditions for preservation of uncharred material and the physical characteristics of the recovered seeds suggest the Morven assemblage is of recent origin. The comparison between the growing plants and the seeds found in subsurface contexts confirms the initial impression. Thus, there is no reason to doubt that nearly all the uncharred seeds so far recovered from Morven are relatively recent.

\section{The Calvert Site}

At Morven, the vegetation survey made interpreting the uncharred seed assemblage relatively straightforward. The Calvert site also yielded uncharred seeds. Preservation is so good that many of the seeds look like they could have been deposited yesterday. What is not clear is how they got to the site. Factors of both deposition and preservation differ from those operating at Morven.
The Calvert site was the home of Captain Charles Calvert, governor of Maryland in the 1720s. It was excavated by Anne Yentsch under the auspices of Historic Annapolis, Inc. Although botanical material was recovered from a variety of contexts at the Calvert site, the present discussion is limited to a comparison of plant remains from two large late 18th century deposits, a well and the crawl space over an abandoned early 18th century hypocaust (Miller 1987).

The lower level of the well contained waterlogged organic material. It seems to have been quickly filled with debris, mostly wood, in the 1760s. The hypocaust, preserved under plexiglass in the Calvert Hotel, lay adjacent to the main house, and was used to heat an orangery. The orangery was demolished ca. 1760, and its hypocaust was quickly filled and sealed with brick rubble, earth, and the floor boards of an overlying building. The crawl space underneath the floor boards was reopened at least twice as further modifications were made to the house in the 1780 s and ca. 1820. The only other documented human disturbance is restricted to the uppermost levels and dates to the late 1970 s, when the site was open for a few years. The deposit was dry and protected, and there is good preservation of other, manufactured organic materials such as leather and cloth.

The excavators recovered seeds from the well and crawl space two different ways. As at Morven, the waterlogged well deposit was floated. During 
TABLE 2

UNCHARRED SEEDS FROM THE CALVERT SITE

\begin{tabular}{|c|c|c|}
\hline & Crawl space & Waterlogged Well \\
\hline $\begin{array}{l}\text { VERY FRAGILE } \\
\text { (WINGED) }\end{array}$ & $\begin{array}{l}\text { maple, } \\
\text { tree-of-heaven }\end{array}$ & maple \\
\hline $\begin{array}{l}\text { FRAGILE } \\
\text { (SMALL WEED SEEDS) }\end{array}$ & & $\begin{array}{l}\text { dock, knotweed, } \\
\text { bullgrass, sedge, } \\
\text { thistle }\end{array}$ \\
\hline $\begin{array}{l}\text { SOMEWHAT } \\
\text { FRAGILE }\end{array}$ & $\begin{array}{l}\text { cantaloupe/muskmelon, } \\
\text { water melon, } \\
\text { acorn, chestnut, } \\
\text { corn cob, squash?, } \\
\text { peanut }\end{array}$ & $\begin{array}{l}\text { cantaloupe/muskmelon, } \\
\text { watermelon } \\
\text { bramble }\end{array}$ \\
\hline $\begin{array}{l}\text { SOMEWHAT } \\
\text { STURDY }\end{array}$ & $\begin{array}{l}\text { grape, acorn, } \\
\text { horsechestnut }\end{array}$ & grape \\
\hline $\begin{array}{l}\text { WOODY } \\
\text { (NUTS) }\end{array}$ & $\begin{array}{l}\text { black walnut, English } \\
\text { walnut, hickory, } \\
\text { almond, Brazil nut, } \\
\text { hazel, pecan }\end{array}$ & $\begin{array}{l}\text { black walnut, English } \\
\text { walnut, hickory }\end{array}$ \\
\hline (FRUIT PITS) & $\begin{array}{l}\text { cherry, peach, plum, } \\
\text { apricot, olive }\end{array}$ & cherry, peach, plum \\
\hline
\end{tabular}

the excavation of the crawl space, all material was screened through either $1 / 4^{\prime \prime}$ or $1 / 16^{\prime \prime}$ mesh, and the excavators picked out what they saw by hand. Fortunately, both waterlogged and dry deposits yielded a wide variety of fruit pits, nutshell, and non-food items.

\section{Physical Properties}

Table 2 lists the Calvert seed types in approximate order of sturdinesss. The winged seeds of tree-of-heaven and maple fall into the most fragile category. Since both types are common and adapted to wind dispersal, post-excavation contamination can explain their presence in either dry or waterlogged 18th century deposits. Alternatively, given the fine preservation conditions, they may date to the original occupation.

The next category includes small weed seeds. Since most of these seeds are less than $1 / 16^{\prime \prime}$ in diameter, it is not surprising that they are found only in the floated samples. The black knotweed seeds look recent because they are very shiny, but the others could all have been scooped up and deposited along with the larger debris when the well was filled.

Exemplars of the remaining three categories are found in both waterlogged and dry contexts, so at least those types seem to be equally easily preserved in dry or wet conditions. Differences between the two assemblages would therefore reflect real differences in the types of seeds originally deposited, not just differences in preservability or archaeological recovery techniques.

\section{Cultural and Natural Sources of the Plant Materials}

How did the seeds get into the deposits? Every seed type found might have fallen on the ground around the late 18th century well. Hickory, black walnut, and wild cherry are all native to eastern North America, and by the 18th century, watermelon, peach (Blake 1981), cherry (Sturtevant 1919), and walnut were widely grown in the colonies. (A real estate advertisement in the 12 June 1760 edition of the Pennsylvania Journal mentions English walnut among the plantings, and 
even earlier references to this tree could probably be found). The grape, whether wild native or cultivated exotic, is also unexceptional. Since the well material comes from a depth of at least 19 feet, except for possible minor post-excavation contamination, it would seem to be as secure a context as an archaeologist is likely to find.

The crawl space presents a problem. By definition, archaeological sites are places of past human activity. That most of the seeds found at the Calvert site are from food plants, many of which are cultigens, would ordinarily come as no surprise. Were they charred, one would assume them to be the refuse of human subsistence activities. However, even though human eating habits may account for the availability of these seeds in 18th century Annapolis, their presence in the crawl space may in part have a different explanation.

Most of the hypocaust/crawl space seeds probably were brought there by the Norway rat (Rattus norvegicus), the black rat ( $R$. rattus), or the Eastern gray squirrel (Sciurus carolinensis). Many gnawed seeds were recovered, including hazel, watermelon, pignut hickory, hickory, pecan, black walnut, English walnut, olive, apricot, peach, plum, and cherry. And Norway rat, black rat, and and squirrel (species not reported) are components of the Calvert site faunal assemblage (Reitz (1988).

Rats and squirrels are common in the midAtlantic; they live near human habitation (unlike, for example, chipmunks), and a list of their dietary preferences reads much like the species list of gnawed seeds. The tooth sizes of rats and squirrels are similar. The gnaw marks on the archaeological material are indistinguishable from those made by gray squirrels (R. Thorington 1988, pers. comm.). Unfortunately, it has not been possible to compare the archaeological material with known ratgnawed specimens. However, direct comparison of the width of the gnaw marks against squirrel incisors (at the Smithsonian Institution) and rat incisors (at the University Museum) suggests that either animal might have gnawed the nuts.

Both the Norway rat and the black rat are preferential ground dwellers. When both types are present in a structure, the Norway rat tends to occupy the more favored lower levels and pushes the black rat to the upper levels (Nowak and Paradiso 1983: 745). Both types "eat everything that people eat and much else" (Nowak and Paradiso 1983: 745), and Grzimek (1975: 358) comments, "Rats generally carry their food back to their burrows, where they consume it. As a result, the burrow contains much edible material which is never eaten." Since the crawl space does not seem to have ever been an open site, and the nuts were found scattered throughout the deposits, R. Thorington (1988, pers. comm.) of the Smithsonian Institution considers rat, rather than squirrel, to be the more likely consumer, especially of household trash items like olive and peach pits.

Squirrels open nuts "by a special levering technique of the lower incisors" (Nowak and Paradiso 1983: 512). They also sometimes "gnaw growing ears of corn . . . and annoy persons by nesting in attics or between walls" (Nowak and Paradiso: 513). Although squirrels usually eat in trees and scatter nutshell on the ground, it is likely that the black walnuts were gnawed by squirrels (Figure 1; R. Thorington 1988, pers. comm.). In any case, evidence of squirrel activity in the crawl space either during the occupation of the building or after its abandonment does not occasion much surprise.

Once it is accepted that interpretations of the crawl space seeds must be filtered through a rodent's food preferences, one may ask questions about the ultimate sources of the seeds. Any items stored or discarded by a Norway rat are likely to have originated close by, for the normal home range of the Norway rat is only about $75-450 \mathrm{ft}$. in diameter (Nowak and Paradiso 1983: 746). With regard to the squirrel, Nowak and Paradiso say, "In the nineteenth century, when native American chestnut was a widespread source of food, tree squirrels are said to have been much more common, and spectacular migrations were reported", (Nowak and Paradiso 1983: 512). The movement of food items, however, would be limited to their ordinary home range, which in Virginia is reported to be an elliptical area averaging 1.32 acres for females and 0.99 acres for males (Doebel and McGinnes 1974). The same study reports home ranges have maximum linear distances of about 


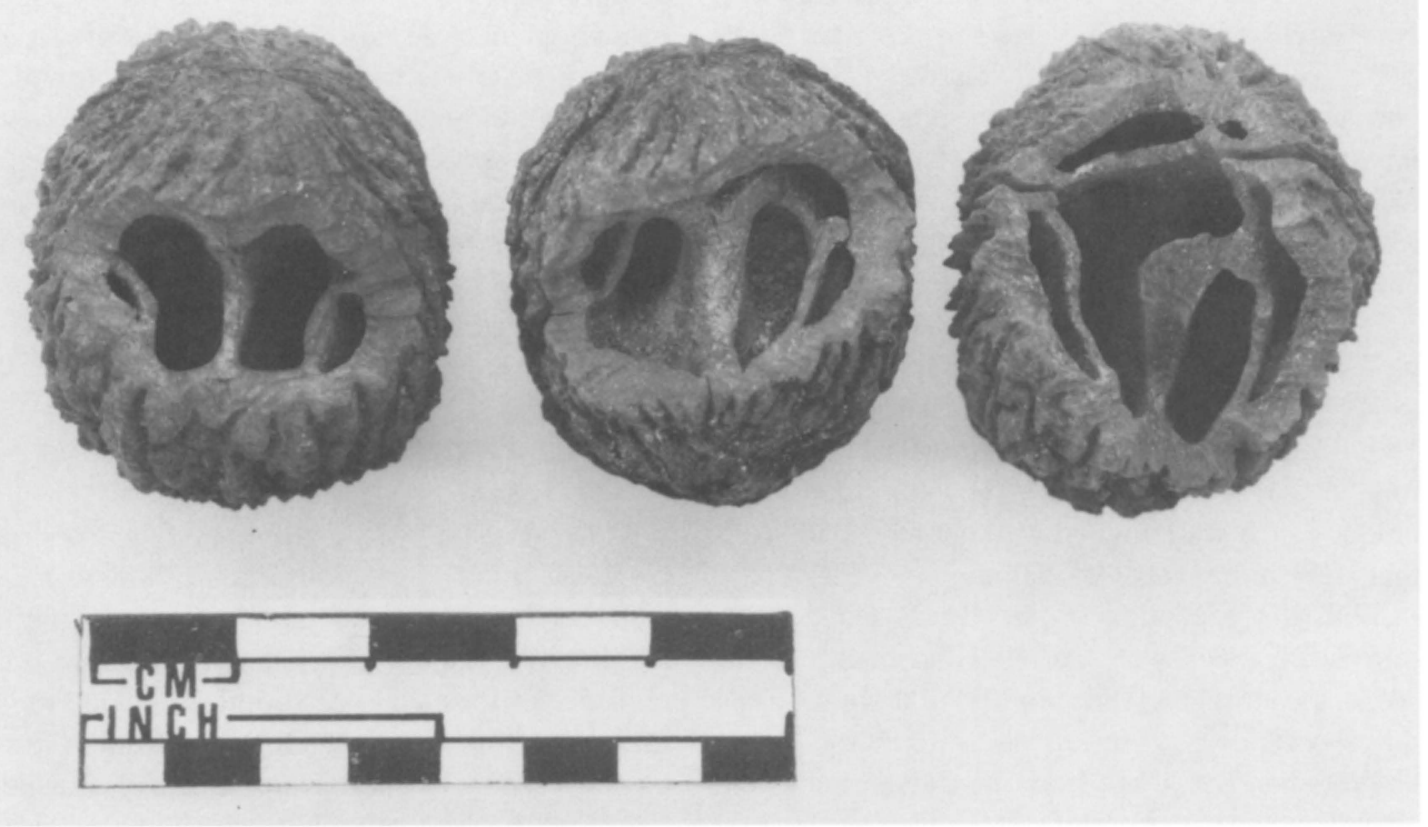

FIGURE 1. Gnawed black walnuts from the crawl space at the Calvert site.

$450 \mathrm{ft}$. In other words, regardless of whether rats or squirrels brought the nuts and seeds to the crawl space, the source of all the gnawed items must have been fairly close to the Calvert house.

If the seeds date to the occupation of the house, then it is reasonable to postulate at least two sources. One, the owners may have been growing quite a variety of native and exotic fruits, both in the orangery and in the gardens and orchards around the house. Or two, the people of the household might have purchased some foods from importers or other growers. The question remains, however, how is it possible to tell whether the seeds were squirreled away by 18 th, 19th, or 20 th century creatures?

Ideally, archaeologists would like to know what was growing near the site throughout its history. With regard to the non-native types, like olive, Brazil nut, English walnut, peach, and watermelon the historical and archaeological record can be searched for the date of their introduction as locally grown crop plants or imported foodstuffs.
Whether native or exotic, it is important to know if each plant type was available in 18th century Annapolis.

\section{Natural Distributions and Anachronisms}

A number of the seed types recovered are native species whose presence is not difficult to explain: maple (box elder), hazel?, oak, hickories, black walnut, some plums and cherries, hackberry, and the grape might all have been growing on the estate in the 18th century or at any time since then.

Several seed types, though not native to Maryland, were grown by the Native Americans of eastern North America prior to European colonization, e.g., corn and pumpkin/squash. Pecan is native to North America and peanut to South America, but the spread of both species to Maryland occurred in the colonial period.

Leonard Blake (1988) examined the corn cobs. Based on purely internal, morphological criteria, 
the corn is a type grown before the modern hybrids were developed 50 to 70 years ago (Leonard Blake 1987, pers. comm.). Since relatively perishable corn cobs can be preserved in the apparently stable environment of the crawl space, the other materials, many of which are even sturdier, are also likely to be older than the 1970s, the only time the site was exposed in modern times.

It is noteworthy that the overlap between the well and the crawl space taxa comprises exactly those types that one would expect to find on an 18th century Maryland farm-fruits and nuts commonly grown at the time. The only seed types unique to the waterlogged well are the small seeds that were retrieved by flotation.

With the exception of the Brazil nut, all the introduced types were definitely available to the colonists during the 18th century. If it were certain that the deposits were left undisturbed by people and rodents, Brazil nut from the Calvert site could actually be used to supplement the historical record of the introduction and spread of some plants. But that is a big "if."

Brazil nut is the most unexpected seed type found at the Calvert site. About four nuts lay at a depth of one to three inches, in a slightly disturbed level; another four lay between three and nine inches, in a late 18th century level; and three lay at a depth of 12 inches, in an early 18th century level. Even today, most of the world's Brazil nuts are uncultivated; growers have not had much success with commercial plantations. Thus, any Brazil nut found in Maryland in the past two centuries is likely to have been imported.

Brazil nut was not described scientifically until the early 19th century (Sturtevant 1919), perhaps because many of the plant hunting expeditions were sponsored by botanical gardens, and Kew, for example, was not established until the middle of the 18th century. According to Rosengarten (1984: 27), Brazil nuts were shipped to Europe by the Dutch and others from the 17th century onward, yet there is no record that they were imported to the United States before 1810. Their presence in 18th century deposits in Maryland is therefore highly problematic.

Explanations for the Brazil nut in the late 18th century deposits of the Calvert site are 1) rodents brought plant materials to the site after the archaeological materials had already been deposited, or 2) the dating of the crawl space layers is too early, or 3) some materials were introduced when repairs to the addition were made in the 19th century, or 4) the historical record is incomplete, and Brazil nut came to the United States through non-commercial or unrecorded channels.

\section{Significance of Calvert Site Assemblage}

Most of what is known about Euro-American plant use and the environment of 18th and early 19th century Maryland comes from the written record. The Calvert site plant remains are direct evidence of food and vegetation. The waterlogged materials from the well all come from common plants, especially cherry and peach. These items may have been intentionally deposited in trash or they may have originated in nearby trees. The material from the crawl space is much more varied and includes many of the well types along with other food plants. Some of these, especially the Brazil nut, were probably imports to Annapolis. Gnaw marks show that many seeds were brought by rodents, either rats or squirrels. The significance of the gnaw marks is not that they prove squirrels and rats lived on the site-this is already knew that from the presence of their bones (Reitz 1987). Rather, these rodents have fairly restricted home ranges, so common or rare, the seeds they buried in the crawl space came from local plants or household trash.

The Calvert assemblage comes from a wealthy urban household. The wide variety of foods recovered may not be typical of other households of the time. Although olives were growing in South Carolina by the end of the 18th century (Sturtevant 1919), and Thomas Jefferson grew them as an ornamental at Monticello (Betts and Perkins 1986), olives may have been imported and probably represent a fairly high status food. The Brazil nuts are even more interesting in this respect, because they suggest that the Calvert family had access to rare, exotic foods. If one could be sure 
that the latest disturbance in the crawl space was ca. 1785 , then it would be possible to begin to specify how food choice might reflect social status (cf., Reitz and Scarry 1985). Additional well dated finds would probably show that the archaeological record extends the written record of Brazil nut back several decades.

\section{Discussion}

As is true of other archaeological remains, it is easier to interpret an archaeological seed assemblage by comparison with seeds from other sites or deposits. Uncharred seeds present particular interpretive problems, for the researcher cannot assume that people brought such plant materials to the site. The Morven and Calvert examples discussed earlier illustrate how one can begin to assess the cultural significance of an excavated seed assemblage. Among the examples presented here, the assemblage with the least secure cultural interpretation is from Morven, where uncharred seeds are neither old nor culturally deposited. The Calvert crawl space assemblage, though somewhat disturbed, most probably reflects 18 th and early 19th century vegetation and food, and the Calvert well assemblage most certainly reflects 18 th century vegetation and food.

Plant remains can be an important source of information about subsistence, farming, and the spread of imported cultigens in the New World. Valid interpretations of any class of archaeological data must take site formation processes into account. Archaeologists should begin to take advantage of the special characteristics of archaeobotanical materials to achieve more reliable reconstructions of land use and economic conditions.

\section{ACKNOWLEDGMENTS}

Gil Stein and Anne Yentsch provided very useful comments on earlier drafts of this paper. I am indebted to Dr. Richard Thorington of the Smithsonian Institution for his help in interpreting the gnaw marks on the Calvert seeds and to Dr.
Leonard Blake of Washington University for analyzing the corn cobs. The New Jersey State Museum and Historic Annapolis, Inc., funded the original projects, directed by Anne Yentsch, on which this paper is based.

\section{REFERENCES}

Betts, Edwin M. and Hazlehurst Bolt Perkins 1986 Thomas Jefferson's Flower Garden at Monticello. (revised by Peter J. Hatch). University of Virginia Press, Charlottesville.

Blake, Leonard W.

1981 Early Acceptance of Watermelon by the Indians of the United States. Journal of Ethnobiology 1:193-99.

1988 Appendix 3. In "The Calvert Site, Annapolis, Maryland: Seed Remains." Calvert Interim Report 7. Ms. on file, Historic Annapolis Inc., Annapolis, Maryland.

Doebel, John H. ANd Burd S. McGinnes

1974 Home Range and Activity of a Gray Squirrel Population. Journal of Wildlife Management 38:860-67.

Fritz, Gayle J.

1984 Identification of Cultigen Amaranth and Chenopods from Rockshelter Sites in Northwest Arkansas. American Antiquity 49:588-72.

Green, Francis W.

1979 Phosphatic Mineralization of Seeds from Archaeological Sites. Journal of Archaeological Science 6:27984.

GRZIMEK, B. (EDITOR)

1975 Grzimek's Animal Life Encyclopedia, Mammals. Van Nostrand Reinhold, New York.

HeER, OsWALD

1878 Abstract of the Treatise on the "Plants of the Lake Dwellings." In The Lake Dwellings of Switzerland and Other Parts of Europe, by F. Keller, translated by J.E. Lee, pp. 518-36. (originally published 1866). Longman's Green and Co., London.

LOCKWOOD, LAURENCE

1988 Estimates of Tree Ages at Morven. In Archaeobotanical Results from the 1987 Excavation at Morven (Princeton, N.J.), edited by Naomi F. Miller and Anne Yentsch. Morven Interim Report 2. Ms. on file, New Jersey State Museum, Trenton, New Jersey.

Lopinot, Neal and David Brussell

1982 Assessing Uncarbonized Seeds from Open-Air Sites in Mesic Environments: An Example from Southern Illinois. Journal of Archaeological Science 9:95-108.

Miksicek, Charles H.

1987 Formation Processes of the Archaeobotanical Record. Advances in Archaeological Method and Theory 10: 211-47. 
Miller, NAOMI F.

1987 Archaeobotanical Remains at the Calvert Site, Annapolis, Maryland. Calvert Interim Report 7. Ms. on file, Historic Annapolis Inc., Annapolis, Maryland.

1988 Vegetation Survey and Macroremains, 1987. In Archaeobotanical Results from the 1987 Excavation at Morven (Princeton, N.J.), edited by Naomi F. Miller and Anne Yentsch. Morven Interim Report 2. Ms. on file, New Jersey State Museum, Trenton, New Jersey.

Minnis, Paul E.

1981 Seeds in Archaeological Sites: Sources and Some Interpretive Problems. American Antiquity 46:14351.

NowaK, Ronald M. and John L. Paradiso

1983 Walker's Mammals of the World (Vol. 1, fourth ed.). Johns Hopkins University Press, Baltimore.

Reinhard, K.J., S.A. MrozowsKi and K.A. Orloski 1986 Privies, Pollen, Parasites and Seeds: A Biological Nexus in Historic Archaeology. MASCA Journal 4:31-36.

ReItz, ElizaBeth J.

1988 Vertebrate Fauna from I8th-Century Annapolis: The Calvert House Site. Calvert Interim Report 6. Ms. on file, Historic Annapolis, Inc., Annapolis, Maryland.
Reitz, Elizabeth J. and C. Margaret Scarry

1985 Reconstructing Historic Subsistence with an Example from Sixteenth-Century Spanish Florida. Society for Historical Archaeology Special Publication 3.

Rock, Carolyn and Lee Newsom

1987 Botanical Analysis of the Privy Pits, Kings Bay Plantation. In Historical Archaeology of Plantations at Kings Bay, Camden County, Georgia, edited by W.H. Adams, pp. 441-442. Reports of Investigations 5, Department of Anthropology, University of Florida, Gainesville.

Rosengarten, Frederic JR.

1984 The Book of Edible Nuts. Walker and Co., New York.

Sturtevant, E. LeWIS

1919 Sturtevant's Notes on Edible Plants, edited by U.P. Hedrick. New York Department of Agriculture, 27th Annual Report, vol. 2, part 2.
NaOMi F. Miller
Museum Applied Science Center For ARCHAEOLOGY
The University Museum
The University of Pennsylvania
33Rd and SPRUCE Streets
Philadelphia, Pennsylvania 19104 
APPENDIX

Latin Names of Plants Mentioned in Text

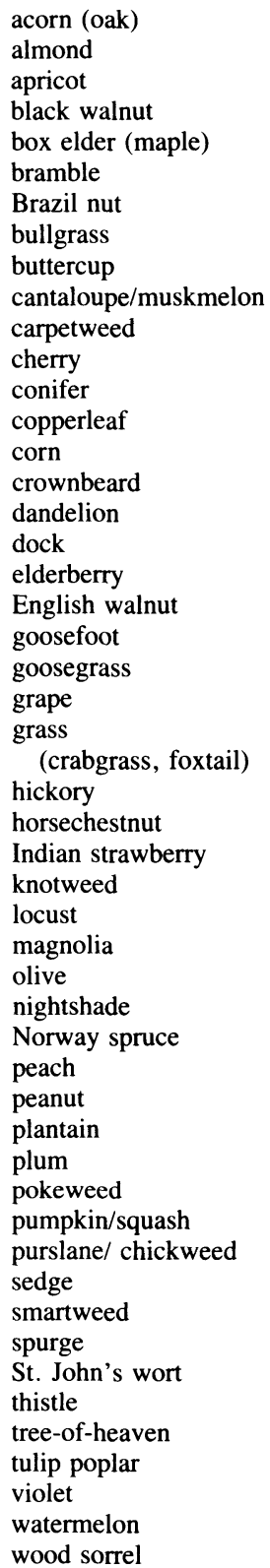

\author{
Quercus \\ Prunus amygdalus \\ Prunus armenaica \\ Juglans nigra \\ Acer cf. negundo \\ Rubus \\ Bertholletia excelsa \\ Paspalum cf. boschianum \\ Ranunculus \\ cf. Cucumis melo \\ Mollugo \\ Prunus sp. \\ Coniferae \\ cf. Acalypha \\ Zea mays \\ cf. Verbesina \\ Taraxacum \\ Rumex \\ Sambucus \\ Juglans regia \\ Chenopodium \\ Eleusine indica \\ Vitis \\ Digitaria, Setaria \\ Carya \\ Aesculus hippocastaneum \\ Duchesnea indica \\ Polygonum \\ Robinia \\ Magnolia \\ Olea europaea \\ Solanum nigrum or $S$. dulcamara \\ Picea abies \\ Prunus persica \\ Arachis hypogaea \\ Plantago \\ Prunus sp. \\ Phytolacca americana \\ cf. Cucurbita \\ Portulaca oleracea/Silene \\ Cyperaceae \\ Polygonum \\ Euphorbia \\ cf. Hypericum \\ Cirsium \\ Ailanthus \\ Liriodendron tulipifera \\ Viola \\ Citrullus \\ Oxalis cf. stricta
}

